\title{
Developing substantive environmental rights
}

\author{
Dinah Shelton \\ Manatt/Ahn Professor of International Law, the George Washington University Law School
}

\begin{abstract}
Human rights tribunals facing claims of violations stemming from environmental degradation are increasingly incorporating and applying national and international environmental standards to assess whether or not the government in question has complied with its legal obligations. The government is required to comply with whatever environmental laws it has enacted as well as treaties to which it is a party. Furthermore the tribunals will assess, albeit with considerable deference, whether or not the environmental laws set the level of protection too low to allow the enjoyment of guaranteed human rights, in some instances drawing on the precautionary principle and other concepts from environmental law.
\end{abstract}

Keywords: environmental rights, precaution, pollution, right to health, procedural rights, access to justice, risk

\section{INTRODUCTION}

Environmental rights ${ }^{1}$ have been proclaimed in two regional human rights treaties, ${ }^{2}$ numerous constitutions, ${ }^{3}$ various environmental instruments ${ }^{4}$ and international

1. The term 'environmental rights', as used herein, refers to any proclamation of a human right to environmental conditions of a specified quality. As discussed, such proclamations utilize a variety of descriptive terms: safe, healthy, ecologically sound, adequate for development, sound, etc.

2. The African Charter of Human and Peoples' Rights provides that '[a]ll peoples shall have the right to a general satisfactory environment favourable to their development': African Charter of Human and Peoples' Rights (27 June 1981) (1982) 21 ILM 58 (African Charter) Art 24. The Additional Protocol to the American Convention on Human Rights provides that 'everyone shall have the right to live in a healthy environment and to have access to basic public services': Organization of American States, Additional Protocol to the American Convention on Human Rights in the Area of Economic, Social and Cultural Rights (17 November 1988) OAS Treaty Series No 6928 ILM 161 [ESC Protocol] Art 11.

3. Since 1972, it has been estimated that more than one-half of all UN member states have added constitutional guarantees concerning the environment, many by declaring or adding an explicit right to a specified quality of the environment: Earthjustice, Environmental Rights Report 2007: Human Rights and the Environment app [2007] (containing constitutional provisions concerning the environment from 118 countries) http://www.earthjustice.org/news/press/ 007/earthjustice-presents-2007-environmental-rights-report-to-un.html (last accessed 13 November 2009). Within the United States, researchers have counted 207 state constitutional provisions in 46 state constitutions that refer to natural resources and the environment. See B Adams et al., 'Environmental and Natural Resources Provisions in State Constitutions' (2002) $22 \mathrm{~J}$ Land Resources \& Envtl L 73. The interpretation and application of some of these provisions is discussed in part 4.1 of this article, above.

4. In addition to the numerous provisions in many environmental agreements referring to rights of information, public participation and access to justice, some of which are listed below (n 5), the Preamble to the Aarhus Convention recognizes that 'adequate protection of the environment is 
declarations. ${ }^{5}$ The phrasing differs among the provisions, which in turn impacts their justiciability and scope. Where such provisions are being enforced nationally and internationally, a growing caseload is elaborating the content of environmental rights. Even when the stated rights are deemed nonjusticiable, as well as when explicit guarantees of environmental rights are lacking, courts often find it necessary to take into account environmental quality in order to ensure the effective enjoyment of other human rights. For these reasons, numerous national and international tribunals today address and provide redress for at least some environmental harm. How they reach their conclusions and give substantive content to environmental rights is the subject of this article.

The article will examine the extent to which the environmental dimension of human rights, in particular the right to a specified environmental quality, has been given content by regional human rights tribunals and national courts through the incorporation of environmental law, principles and standards. It concludes that such bodies increasingly utilize environmental standards to adjudicate human rights claims related to the environment and to judge whether or not States have complied with their legal obligations.

\section{PROCEDURE AND SUBSTANCE}

In general, procedural human rights linked to environmental protection receive more attention than do substantive environmental rights in legal instruments, ${ }^{6}$ jurisprudence $^{7}$ and in doctrine. ${ }^{8}$ The focus on procedural rights has been based in part

essential to human well-being and the enjoyment of basic human rights, including the right to life itself': Convention on Access to Information, Public Participation in Decision-Making and Access to Justice in Environmental Matters (25 June 1998) Doc ECE/CEP/43 (Aarhus Convention).

5. 'Declaration of the UN Conference on the Human Environment, princ 1' (16 June 1972) (1973) UN Doc A/CONF.48/14/Rev 1; 'UN Conference on Environment and Development: Rio Declaration on Environment and Development' (1992) UN Doc A/CONF.151/5/Rev 1 reprinted in 31 ILM 874; 'Draft Declaration of Principles on Human Rights and the Environment' UN Hum Rts Comm (16 May 1994). See also, UNGA Res 45/94, in which the General Assembly recognizes that 'all individuals are entitled to live in an environment adequate for their health and well-being...': 'Need to Ensure a Healthy Environment for the Well-Being of Individuals' GA Res 45/94 (1990) UN GAOR 45th Session UN Doc A/RES/45/94.

6. Most environmental agreements now contain provisions calling for public information and participation. See, eg, Convention on Civil Liability for Damage Resulting from Activities Dangerous to the Environment (Lugano 21 June 1993) Art 13-16; North-American Agreement on Environmental Co-operation (13 September 1993) Art 2(1)(a); International Convention to Combat Desertification in those Countries Experiencing Serious Drought and/or Desertification, particularly in Africa (Paris 17 June 1994) Preamble, Arts 10(2)(e), 13(1)(b), 14(2), 19, and 25; Convention on Co-operation and Sustainable Use of the Danube River (Sofia 29 June 1994) Art 14; Protocol on Water and Health to the 1992 Convention on the Protection and use of Transboundary Watercourses and International Lakes (London 17 June 1999) Art 5(i); Cartagena Protocol on Biosafety to the Convention on Biological Diversity (Montreal 29 January 2000) Art 23. See in particular, the Aarhus Convention, (n 3).

7. See, for example, Apirana Mahuika et al v New Zealand Comm No 547/1992, CCPR/C/ 70/D/547/1993, views issued 16 November 2000, in which the Human Rights Committee found no violation of Maori fishing rights, emphasizing that they had the opportunity to participate in the decision-making process relating to the fishing measures adopted.

8. See, for example, S Atapattu, 'The Right to a Healthy Life or the Right To Die Polluted? The Emergence of a Human Right to a Healthy Environment Under International Law' (2002) 16 Tul Envtl LJ 65, 72-73. 
on political caution, at least at the international level, arising from concern that efforts to guarantee and enforce substantive environmental rights may be unsuccessful. ${ }^{9}$ Indeed, the claim of a human right to environmental quality has met resistance from those who argue that the concept cannot be given content and that no justiciable standards can be developed to enforce the right, because of the inherent variability of environmental conditions. ${ }^{10}$

Some proponents of procedural rights also may have held an overly optimistic view that a fully informed public with rights of participation in environmental decision-making, and access to remedies for environmental harm, would ensure a high level of environmental protection. Such a beneficial outcome may result, but it cannot always be assured. ${ }^{11}$ Democratic states as well as dictatorial regimes have adopted pernicious laws at different moments in history, laws that imposed racial segregation, press censorship, forced sterilization, and other odious substantive outcomes. In a democracy, such results can occur despite an informed public and an adherence to democratic process. In the environmental field, well-known problems of achieving environmental protection in the face of short-term economic costs, as well as scientific uncertainty or the perception thereof, make reliance on procedure alone insufficient to ensure a safe, healthy or ecologically sound environment.

The danger of placing confidence in the decision-making process is illustrated by Zander $v$ Sweden, ${ }^{12}$ where the applicants complained about contamination of their well water by cyanide from a neighbouring dump site. The municipality initially furnished temporary water supplies, but later, adhering to the normal regulatory procedures, the town raised the permissible level of cyanide in the city water supply. The permit for the dump was later renewed and expanded, while the applicant's request for safe drinking water was denied. ${ }^{13}$

Human rights, enshrined in international and constitutional law, set the limits of majority rule as well as provide protection against dictatorial repression. The scope and contours of substantive as well as procedural rights are sometimes detailed in

9. See, eg, A-Ch Kiss, 'Peut-on définir le droit de l'homme à l'environnement?' [1976] Rev Juridique de l'environnement 15; A. Kiss, 'Le droit à la conservation de l'environnement' (1990) 2 Rev Univ des Droits de l'homme 445; A. Kiss, 'An Introductory Note on a Human Right to Environment' in E Brown Weiss (ed), Environmental Change and International Law (UNU, Tokyo 1992) 551.

10. See, for example, G Handl, 'Human Rights and Protection of the Environment: A Mildly Revisionist View' in AA Cancado Trindade (ed), Human Rights and Environmental Protection (IIHR, San Jose, Costa Rica 1992); A Boyle and M Anderson (eds), Human Rights Approaches to Environmental Protection (Clarendon Press, Oxford 1996).

11. See M Paellemarts, 'The Human Right to a Healthy Environment as a Substantive Right' in M Dejeant-Pons and M Paellemarts (eds), Human Rights and the Environment (Council of Europe, Strasbourg 2002) 11, 15.

12. Zander v Sweden (App no 14282/88) (1993) Eur Ct Hum Rts Series A no 279B. Admittedly, it was the denial of judicial review of this decision that formed the basis of Lander's successful claim before the European Court. The Court, finding that the applicants had a right to clean water under Swedish law, held that the lack of judicial review violated the European Convention, Art 6(1) because the applicants were entitled as of right to seek precautionary measures against water pollution.

13. The European Court did not actually have to reach a conclusion on the substance of this decision, because it found that the applicant's procedural right of access to justice under Art 6 was violated. The applicants had been unable to obtain judicial review by Swedish courts of the board's permitting decision. 
legislation, but they are also given content through litigation. International human rights tribunals in particular elaborate on the often generally stated rights whose implementation they monitor.

Apart from the African Commission on Human and Peoples' Rights, no international human rights tribunal monitors compliance with a treaty-based 'right to environment' provision, because no such right was written into UN human rights treaties or the European ${ }^{14}$ and American ${ }^{15}$ Conventions. Instead UN treaty bodies and the Inter-American and European tribunals hear complaints about failures to enforce national environmental rights ${ }^{16}$ or about environmental degradation that violates one or more of the guaranteed rights in the agreements over which they have jurisdiction. ${ }^{17}$ The general treaty interpretation rules of the Vienna Convention on the Law of Treaties (VCLT), ${ }^{18}$ especially Article 31(3), and interpretive principles developed by human rights tribunals to ensure the effective enjoyment of rights have proven particularly important in giving substance to environmental rights.

\section{INTERPRETING HUMAN RIGHTS GUARANTEES}

The VCLT calls for the terms of a treaty to be interpreted in good faith in accordance with their ordinary meaning in the context of the whole agreement and in the light of its object and purpose. ${ }^{19}$ VCLT Article 31(3) adds several paragraphs designed to ensure that the treaty as a whole is also placed in context. It requires that there be taken into account subsequent agreements between the parties regarding the interpretation of the treaty or the application of its provisions, any subsequent practice which establishes an agreement of the parties regarding its interpretation and 'any relevant rules of international law applicable in the relations between the parties'. Thus no agreement stands in isolation, but it must always be considered along with other treaties, customary international law and general principles of law relevant to the issue.

In addition to the general structure of treaty interpretation set forth in the VCLT, regional human rights instruments contain specific provisions on interpretation. The European Convention, Article 53, for example, provides that nothing in the Convention shall be construed as limiting or derogating from any of the human rights and fundamental freedoms which may be ensured under the laws of any Contracting Party or under any other agreement to which it is a Party. ${ }^{20}$ The American Convention

14. European Convention for the Protection of Human Rights and Fundamental Freedoms (4 November 1950) 213 UNTS 221 (ETS 5) (European Convention).

15. American Convention on Human Rights (22 November 1969) 1114 UNTS 123 OASTS No 36 (American Convention).

16. In many of the cases discussed, the applicants cite constitutional provisions guaranteeing the right to a safe and healthy or other quality environment. See, eg, Okyay v Turkey (App no 36220/97) EurCtHR Reports of Judgments and Decisions (Reports) 2005-VII (12 July) (2006) 43 EHRR 788 and Kyrtatos v Greece (App no 4666/98) Reports 2003-VI (22 May) (extracts) discussed at (n 96 and 128).

17. Most commonly invoked are the rights to life, health, property, culture, information, privacy and home life. See D Shelton, 'Human Rights and the Environment: What Specific Environmental Rights Have Been Recognized'? (2006) 35 Denv J Int'l L \& Pol'y 129.

18. Vienna Convention on the Law of Treaties (23 May 1969) 1155 UNTS 331 (VCLT) Arts 31 and 32 .

19. Ibid Art 31(1).

20. European Convention (n 14) Art 53. 
on Human Rights goes further, safeguarding not only rights recognized by domestic laws and other agreements, but also the American Declaration of the Rights and Duties of Man and 'other international acts of the same nature' as well as 'other rights or guarantees that are inherent in the human personality .... ${ }^{21}$ The African Charter of Human and Peoples' Rights contains the broadest mandate, calling on its Commission to draw inspiration from international law on human and peoples' rights, other instruments adopted by the United Nations and by African countries in the field of human and peoples' rights and the provisions of instruments adopted by specialized agencies. $^{22}$ As subsidiary means to determine the relevant principles of law, the Commission is directed to take into consideration other general or special international conventions, African practices consistent with international norms on human and peoples' rights, customs generally accepted as law, general principles of law recognized by African states and legal precedents and doctrine. ${ }^{23}$

The broad interpretive mandates of regional bodies have led to the practice of finding and applying the most favourable rule to individuals appearing before the courts and commissions. ${ }^{24}$ In addition, human rights tribunals have developed various canons of interpretation that reinforce these mandates and the VCLT rules of treaty interpretation, allowing them to make broad use of environmental laws, principles and standards.

Using the VCLT, human rights bodies accept the primacy of the texts of human rights treaties, whose basic purpose is the protection of the rights of the individual. Based on this purpose, tribunals interpret the rights guaranteed in a dynamic manner. The Inter-American Court has referred to 'evolving American law' and the need to interpret legal instruments in the light of contemporary standards. ${ }^{25}$ Neither the Inter-American Commission nor the Court adheres to a static or 'originalist' interpretation of the texts. Instead, both institutions have held that the provisions of regional human rights instruments must be interpreted and applied by taking into account 'developments in the field of international human rights law since those instruments were first composed and with due regard to other relevant rules of international law applicable to member states against which complaints of human rights violations are properly lodged'. ${ }^{26}$ The jurisprudence of the Inter-American system reveals that

21. American Convention (n 15) Art 29.

22. African Charter (n 2) Art 60.

23. Ibid para 61 .

24. See, for example, Compulsory Membership in an Association Prescribed by Law for the Practice of Journalism, Advisory Opinion OC-5/85, Inter-American Court of Human Rights Series A No 5 (13 November 1985) para 52, finding that if the American Convention and another international treaty are applicable, the rule most favourable to the individual must prevail.

25. Interpretation of the American Declaration of the Rights and Duties of Man within the Framework of Article 64 of the American Convention on Human Rights, Advisory Opinion OC-10/89, Inter-American Court of Human Rights Series A No 10 (14 July 1989), citing Legal Consequences for States of the Continued Presence of South Africa in Namibia (South West Africa) notwithstanding Security Council Resolution 276 (1970) (1971) Advisory Opinion ICJ Rep 16, 31.

26. See Advisory Opinion OC-10/89 (n 46) para 37; I/A Court HR, Advisory Opinion OC-16/ 99, The Right to Information on Consular Assistance in the Framework of the Guarantees of the Due Process of Law, Inter-American Court of Human Rights Series A No 16 (1999) (Advisory Opinion OC-16/99) para 114 (endorsing an interpretation of international human rights 
relevant developments in the corpus of international human rights law may be drawn from the provisions of other international and regional instruments. ${ }^{27}$

The European Court of Human Rights has also determined that it must have regard to the changing conditions within its Contracting States generally and must respond to evolving convergence as to the standards to be achieved. The European Court maintains this dynamic and evolutive approach because it finds it is 'of critical importance that the Convention is interpreted and applied in a manner which renders its rights practical and effective, not theoretical and illusory'. ${ }^{28}$ Such an approach benefits environmental rights, which might be excluded from consideration using an 'originalist' interpretation of human rights agreements, because most of the latter were written before environmental law developed and thus environmental conditions were not contemplated by the treaty drafters. ${ }^{29}$

Applying its evolutive approach, the European Court has indicated that the scope of guaranteed rights is affected by the 'growing and legitimate concern both in Europe and internationally about offenses against the environment'. ${ }^{30}$ It thus concluded that governments may adjust the amount of permissible bail that can be demanded and the length of pre-trial detention according to the particular circumstances of an environmental disaster. ${ }^{31}$ In reaching this conclusion, the Court

instruments that takes into account developments in the corpus juris gentium of international human rights law over time and in present-day conditions); Report No 52/02, Case No 11.753, Ramón Martinez Villareal (United States), Annual Report of the IACHR 2002, para 60. 27. See Advisory Opinion OC-10/89 (n 25) para 37; Advisory Opinion OC-16/99 (n 26) para 115; Report No 52/01, Case No 12.243, Juan Raul Garza (United States), I/A Comm Annual Report 2000, paras 88, 89 (confirming that while the Commission does not apply the American Convention in relation to member states that have yet to ratify that treaty, its provisions may well be relevant in informing an interpretation of the principles of the Declaration).

28. Christine Goodwin v The United Kingdom [GC], (App no 28957/95) (Judgment of 11 July 2002) (2002) 35 EHRR 18, para 74.

29. Recall that the VCLT allows recourse to the drafting history (travaux préparatoires) as a subsidiary means of interpretation (Art 32) only if the application of Art 31 leaves the meaning absurd or ambiguous.

30. See Mangouras $v$ Spain (App no 12050/04) 8 January 2009, para 41 (referred to a Grand Chamber 5 June 2009). Increased concern with the environment has also proved important in cases where states have taken measures to protect the environment and the actions are resisted on the grounds that they interfere with the right to property. In Fredin v Sweden, the applicant argued that nature protection was an inadequate reason to revoke a license to extract gravel on his property and therefore was a violation of Art 1 , Protocol 1 . The Court found no violation, noting that the protection of the environment is an increasingly important consideration: Fredin $v$ Sweden (App no 12033/86) (1991) 13 EHRR 784.The Court similarly found no violation of the same provision in Pine Valley Developments Ltd v Ireland, where permission to carry out construction in a green belt area was revoked on grounds of environmental protection: Pine Valley Developments Ltd v Ireland (App no 12742/87) (1992) 14 EHRR 319. The most difficult and contentious cases in this respect have concerned travellers or gypsies, whose lifestyle may bring them into contact with modern land use planning. The European Court has repeatedly refused to override local zoning restrictions, especially the creation of green belts, in order to ensure a permanent home for this minority group: See Buckley v United Kingdom (1996) Eur Ct HR 1996-IV 1271 and the four recent cases: Smith v United Kingdom (App no 25154/94) (2001) 33 EHRR 712; Lee v United Kingdom (App no 25289/94) (2001) 33 EHRR 677; Chapman v United Kingdom (App no 27238/94) (2001) 33 EHRR 399; Beard v United Kingdom (App no 24882/94) (2001) 33 EHRR 442.

31. Mangouros v Spain, ibid. 
took into account the 1982 Convention on the Law of the Sea and its provisions on offences against the marine environment, MARPOL, ${ }^{32}$ and European law on environmental crimes and liability. ${ }^{33}$

Interpreting human rights by reference to other legal instruments and principles is increasingly common. The European Court in 2008 described its methodology in detail and provided a useful framework for future cases. Demir and Baykara v Tur$k e y,{ }^{34}$ a case concerning trade union freedoms, is the fullest exposition to date of the Court's views on the relevance of other legal instruments and general principles in instances where the European Convention is silent or lacking precision. The Turkish Government argued against reliance on international instruments other than the Convention, on the ground that such reliance would risk wrongly creating, by way of interpretation, new obligations not contained in the Convention. In particular, the Government contended that an international treaty to which the party concerned had not acceded could not be relied upon against it by reference to VCLT Article 31(3)(c) ${ }^{35}$ The Court disagreed.

The Court began with a summary of the principal VCLT rules of interpretation, which it deemed mandatory to determine the meaning of the terms and phrases used in the Convention. ${ }^{36}$ Thus 'the Court is required to ascertain the ordinary meaning to be given to the words in their context and in the light of the object and purpose of the provision from which they are drawn'. ${ }^{37}$ VCLT Article 32 allows recourse to supplementary means of interpretation, either to confirm a meaning or to establish the meaning where it would otherwise be ambiguous, obscure or manifestly absurd or unreasonable. $^{38}$

The Court referenced VCLT Article 31(3)(c) in particular, in adding that the Court 'has never considered the provisions of the Convention as the sole framework of reference for the interpretation of the rights and freedoms enshrined therein. On the contrary, it must also take into account any relevant rules and principles of international law applicable in relations between the Contracting Parties'. 39

32. International Convention for the Prevention of Pollution from Ships, 2 November 1973 (MARPOL 73/78) and the Protocol thereto adopted 17 February 1978.

33. The Court cited two European Community directives, Directive 2004/35/CE of 21 April 2004 on environmental liabitility with regard to the prevention and remedying of environmental damage and Directive 2005/35/EC of 7 September 2005 on ship-source pollution and on the introduction of penalties for infringements.

34. Demir and Baykara v Turkey [GC] (App no 34503/97) 12 November 2008.

35. Ibid para 55.

36. Although the VCLT by its own terms is not retroactive to govern an agreement written in 1950, the Court accepts that the VCLT rules of interpretation reflect customary international law. See, eg, Golder v the United Kingdom (21 February 1975) §29, Series A no 18; Johnston and Others $v$ Ireland (18 December 1986) $\$ \$ 51$ et seq., Series A no 112; Lithgow and Others $v$. the United Kingdom, (8 July 1986) §§114 and 117, Series A no 102 and Witold Litwa v Poland, no 26629/95, §§57-59, Reports 2000-III.

37. Demir and Baykara (n 34) para 65, citing Golder ibid; Johnston and Others, ibid and Art $31 \S 1$ of the Vienna Convention.

38. Demir and Baykara ibid, citing Saadi v the United Kingdom [GC], no. 13229/03, § 62, Reports 2008.

39. Ibid para 67, citing Saadi, §62; Adsani v the United Kingdom [GC], no. 35763/97, §55, Reports 2001-XI and Bosphorus Hava Yollari Turizm ve Ticaret Anonim Şirketi v Ireland [GC], no 45036/98, §150, Reports 2005-VI. 
The Court also cited its earlier jurisprudence on the Convention as a 'living instrument', which 'must be interpreted in the light of present-day conditions', taking into account 'evolving norms of national and international law in its interpretation of Convention provisions'. 40

The remainder of the Court's analysis pointed to the variety of sources that are relevant to this general approach, first looking to other international human rights treaties that are applicable in the particular sphere, ${ }^{41}$ and then to 'general principles of law recognized by civilized nations' as mentioned in Article $38 \S 1$ (c) of the Statute of the International Court of Justice. ${ }^{42}$ According to the European Court, general principles of law may be identified in texts of universal and regional scope (not only human rights treaties) and in the jurisprudence of international ${ }^{43}$ and domestic courts ${ }^{44}$ that apply these instruments. In addition, the Court may use 'intrinsically non-binding instruments of Council of Europe organs, in particular recommendations and resolutions of the Committee of Ministers and the Parliamentary Assembly'. ${ }^{45}$ The Court may further 'support its reasoning' by reference to norms emanating from other Council of Europe organs, whether supervisory mechanisms or expert bodies. ${ }^{46}$

In sum, the European Court considers the object and purpose of the Convention provisions, but

it also takes into account the international law background to the legal question before it. Being made up of a set of rules and principles that are accepted by the vast majority of States, the common international or domestic law standards of European States reflect a reality that the Court cannot disregard when it is called upon to clarify the scope of a Convention provision that more conventional means of interpretation have not enabled it to establish with a sufficient degree of certainty. ${ }^{47}$

40. Ibid para 68, citing Soering v the United Kingdom (7 July 1989) §102, Series A no 161; Vo v France [GC], no 53924/00, §82, Reports 2004-VIII and Mamatkulov and Askarov v Turkey [GC], nos 46827/99 and 46951/99, §121, Reports 2005-I.

41. Ibid para 69, noting that the Court has interpreted Art 8 of the Convention in the light of the United Nations Convention of 20 November 1989 on the Rights of the Child and the European Convention on the Adoption of Children of 24 April 1967 in Pini and Others v Romania, nos 78028/01 and 78030/01, $\S 139$ and 144, ECHR 2004-V and Emonet and Others $v$ Switzerland, no 39051/03, §§65-66, ECHR 2007-. In Siliadin v France, no 73316/01, §§85-87, ECHR 2005-VII the Court in order to establish the State's positive obligation concerning 'the prohibition on domestic slavery' took into account the provisions of the ILO Forced Labour Convention, the Supplementary Convention on the Abolition of Slavery, the Slave Trade, and Institutions and Practices Similar to Slavery, and the International Convention on the Rights of the Child.

42. Statute of the International Court of Justice, Art 38 (1). The European Court noted that the Legal Committee of the Consultative Assembly of the Council of Europe foresaw in August 1950 that 'the Commission and the Court [would] necessarily [have to] apply such principles' in the execution of their duties and thus considered it to be 'unnecessary' to insert a specific clause to this effect in the Convention (Documents of the Consultative Assembly, working papers of the 1950 session, Vol III, no 93, p 982, para 5).

43. For example, judgment of the International Criminal Tribunal for the Former Yugoslavia in Prosecutoer v Furundzija, Case IT-95-17/1 (Appeals Chamber) (2002) 121 Int'1 L Rep 213. 44. Eg, Regina v Bartle, Bow Street Stipendiary Magistrate ... Commissioner of Police, ex p Pinochet (No 3), House of Lords (24 March 1999) 2 WLR 827, (1999) 38 ILM 581.

45. Demir and Baykara (n 34) para 77.

46. Ibid.

47. Ibid para 80 . 
When common ground among the norms is found, the Court will not distinguish between sources of law according to whether or not they have been signed or ratified by the respondent State. ${ }^{48}$ It is sufficient for the Court that the relevant international instruments denote a continuous evolution in the norms and principles applied in international law or in the domestic law of the majority of member States of the Council of Europe and show, in a precise area, that there is common ground in modern societies.

It remains to be seen how far national and international tribunals have proceeded in making use of environmental norms to give substance to environmental rights.

\section{USING ENVIRONMENTAL LAW TO GIVE SUBSTANCE TO ENVIRONMENTAL HUMAN RIGHTS}

Human rights tribunals have given effect to various human rights linked to environmental protection by reference to international environmental principles, standards and norms. In addition, they have emphasized the importance of giving effect to national environmental rights provisions. In so doing they have given substantive content to environmental rights and corresponding state obligations. To give two examples at the outset, in its Öneryildiz v Turkey ${ }^{49}$ judgment, the European Court referred to the Convention on Civil Liability for Damage resulting from Activities Dangerous to the Environment ${ }^{50}$ and the Convention on the Protection of the Environment through Criminal Law ${ }^{51}$ despite the fact that the majority of member States, including the respondent State, had neither signed nor ratified the two Conventions. In the Tasskin and Others $v$ Turkey ${ }^{52}$ case, the Court built on its case-law concerning Article 8 of the Convention in matters of environmental protection, largely on the basis of principles enshrined in the Aarhus Convention on Access to Information, Public Participation in Decision-making and Access to Justice in Environmental Matters. ${ }^{53}$ Turkey had not signed the Aarhus Convention.

\subsection{The environmental quality guaranteed by international and national law}

Both national and international courts have used environmental law and science to give content to the level of environmental protection required by human rights law. This approach can involve reference to World Health Organization (WHO) standards on acceptable emissions levels, incorporation of the precautionary principle to judge the adequacy of measures taken by a government or reference to environmental treaties and declarations. The breadth of the search for standards depends in part on whether or not there is a textual guarantee of environmental quality and, if there is, on the descriptions of that quality.

48. Ibid para 78 .

49. Oneryildiz v Turkey [GC], Reports 2004-VI (30 November).

50. ETS No 150 - Lugano, 21 June 1993.

51. ETS No 172 - Strasbourg, 4 November 1998.

52. Taşkin and Others v Turkey, no 49517/99, §§99 and 119, 2004-X (2005) Eur Ct HR 145.

53. Aarhus Convention (n 4). 
At the national or provincial level, constitutional provisions vary in the chosen description of the environmental quality that is protected. While many of the older provisions refer to a 'healthy' or 'healthful' environment, more recent formulations add references to ecology and/or biodiversity to the guarantee, although the right may be stated in a limited manner. The Quebec provincial Charter, for example, provides 'Every person has a right to live in a healthful environment in which biodiversity is preserved, to the extent and according to the standards provided by law'. ${ }^{54}$ The French Constitution, amended to add a Charter of the Environment in $2005,{ }^{55}$ affords French citizens the right to live in a 'balanced environment, favorable to human health' ${ }^{56}$ The French Conseil Constitutionnel has used the Charter to review legislative enactments, ${ }^{57}$ finding that the Charter constitutes a 'fundamental freedom' of constitutional value allowing for the suspension of an administrative decision under French procedural law. ${ }^{58}$ Eastern European countries have also altered or changed their constitutions since the fall of the Soviet Union to include a substantive right to the environment, and courts have found these rights justiciable. ${ }^{59}$ In Latin America, Article 19 of the 1980 Constitution of Chile provides for a 'right to life' and a 'right to live in an environment free of contamination' and establishes that certain other individual rights may be restricted to protect the environment. ${ }^{60}$ The Government of Chile is required to 'ensure that the right to live in an environment free of contamination is not violated' and to 'serve as a guardian for and preserve nature/the environment'. ${ }^{61}$

54. Quebec Charter of Human Rights and Freedoms, RSQ, c C-12, s 46.1.

55. Charter for the Environment, Art 1, <http://.legifrance.gouv.fr/html/constitution/const03.htm> (last accessed 13 November 2009). See generally O Pedersen, 'European Environmental Human Rights and Environmental Rights: A Long Time Coming?' (2008) 21 Georgetown Int'l Envt'l L Rev 73; D Marrani, 'The Second Anniversary of the Constitutionalisation of the French Charter for the Environment: Constitutional and Environmental Implications', (2008) 10 Env L Rev 9; JR May, 'Constituting Fundamental Environmental Rights Worldwide', (2005-2006) 23 Pace Envtl L Rev 113, 113-14.

56. Legifrance, Charter for the Environment, Art 1, <http://www.legifrance.gouv.fr/html/ constitution/const03.htm> (last accessed 13 November 2009).

57. See, eg, Conseil Constitutionnel Decision No 2005-514DC, 28 April 2005, R 305 (Loi relative à la création du registre international français); Marrani ( $\mathrm{n} 45)$.

58. See Marrani (n 55) 21-22.

59. The Hungarian Constitution, for example, states, 'Hungary recognizes and implements everyone's right to a healthy environment': A Magyar Küztársaság Alkotmánya [Constitution] Art 18 (Hung.), translated in AP Blaustein and GH Flanz (eds) Constitutions of the Countries of the World (Dobbs Ferry, New York 1998); see also, G Badni, 'The Right to Environment in Theory and Practice: The Hungarian Experience', (1993) 8 Conn J Int'l L 439.

60. Chile Const, Art $19 \S \S 1,8$.

61. Ibid Art 19, §8. In 1988, the Supreme Court of Chile held that the constitutionalenvironmental provisions established a substantive right. Residents of the village of Chanaral filed suit against a government-run copper mine to restrain the company from continuing to discharge tailings on local beaches and coves. Based on a site visit, the Court found much of the shore and local waters inert and enjoined further dumping within 1 year: Pedro Flores y Otros v Corporacion Del Cobre, Codeloco, Division Salvador. Recurso de Proteccion, (1988) 12.753.FS. 641 (Chile), <http://www.unescap.org/drpad/vc/document/compendium/ chl.htm> (summary) (last accessed 13 November 2009). 
States in the US have the power to provide their citizens with rights additional to those contained in the federal constitution, ${ }^{62}$ and state constitutions revised or amended from 1970 to the present have added environmental protection among their provisions. ${ }^{63}$ To mark the occasion of the first Earth Day in 1970, the Pennsylvania legislature adopted a proposed amendment to the state constitution, ${ }^{64}$ subsequently approved overwhelmingly by voters in the state, ${ }^{65}$ and added what is now Article I, section 27 to the state constitution:

\section{Section 27. Natural resources and the public estate}

The people have a right to clean air, pure water, and to the preservation of the natural, scenic, historic and aesthetic values of the environment. Pennsylvania's public natural resources are the common property of all the people, including generations yet to come. As trustee of these resources, the Commonwealth shall conserve and maintain them for the benefit of all the people.

The amendment and others like it were intended to elevate environmental protection as a fundamental value to a constitutional status above the states' legislative and regulatory norms and to protect the environment beyond issues of human health. ${ }^{66} \mathrm{~A}$ second aim was to expand standing to sue to allow public interest litigation on behalf of the

62. The United States federal constitution does not mention the environment - unsurprising given that the constitution was written in 1789. Nonetheless in 1968, the same year the government of Sweden proposed to the United Nations that it convene its first international conference on the human environment, US Senator Gaylord Nelson introduced a draft constitutional amendment that would have recognized in the Bill of Rights that '[e]very person has the inalienable right to a decent environment'. The proposal failed, as have later attempts to recognize such a right. See HR J Res 1321, 90th Cong, 2nd Session (1968); HR J Res 1205, 91st Cong, 2nd Session (1970). Most recently, Representative Jesse Jackson, Jr. proposed a constitutional amendment 'respecting the right to a clean, safe, and sustainable environment': HR J Res 33, 108th Cong (2003).

63. See Ala Const Art VIII; Cal Const Art X, §2; Fla Const Art II, §7; Haw Const Art XI; Ill Const Art XI; La Const Art IX; Mass Const §179; Mich Const Art IV, §52; Mont Const Art IX, §1; NM Const Art XX, §21; NY Const Art XIV; NC Const Art XIV, §5; Ohio Const Art II, §36; Pa Const Art I, §27; RI Const Art 1, §17; Tex Const Art XVI, §59; Utah Const Art XVIII; Va Const Art XI, §1. For discussions of these provisions, see AE Dick Howard, 'State Constitutions and the Environment' (1972) 58 Va L Rev 193,229; RM Frye, Jr., 'Environmental Provisions in State Constitutions' (1975) 5 Envtl L Rep 50028-29; SG Pollock, 'State Constitutions, Land Use, and Public Resources: The Gift Outright' [1984] Ann Surv Am L 13, 28-29; RA McLaren, 'Comment, Environmental Protection Based on State Constitutional Law: A Call for Reinterpretation' (1990) 12 U Haw L Rev 123, 126-27; CL Gallagher, 'The Movement to Create an Environmental Bill of Rights: From Earth Day 1970 to the Present' (1997) 9 Fordham Envtl LJ 107.

64. FL Kury, The Pennsylvania Environmental Protection Amendment, Pa B Ass'n Q, April 1987, at 85, 87, quoted in Kirsch (n 30) at 1170.

65. The vote was more than 3-1 in favour of the amendment, with close to 2 million voters. See FL Kury, 'The Environmental Amendment to the Pennsylvania Constitution: Twenty Years Later and Largely Untested' (1990) 1 Vill Envtl LJ 123, 123-24 in Kirsch, (n 30) at note 3. 66. The Pennsylvania Supreme Court has indicated that environmental litigants may sue for generalized harm because '[a]esthetic and environmental well-being are important aspects of the quality of life in our society' and because its constitution establishes a local government's duty to protect its citizens' 'quality of life'. Commonwealth, Pa Game Comm'n v Commonwealth, Dept of Envtl Resources, 509 A.2d 877, 883-84 (Pa Comm2 Ct 1986) aff'd 555 A.2d 812 (Pa 1989). 
environment. ${ }^{67}$ Illinois, Massachusetts ${ }^{68}$ and Montana ${ }^{69}$ all amended their constitutions in 1972 to provide in similar fashion for a right to a clean and healthful environment. The scope and content of this right has been a subject of litigation in all of these states.

The Supreme Court of Montana has provided the most detail about the substantive implications of a right to a specified environmental quality. In Montana Environmental Information Center et al $v$ Department of Environmental Quality, ${ }^{70}$ the plaintiffs contended that the Constitution's environmental protections were violated by the legislature when it amended state law to provide a blanket exception to requirements governing discharges from well water without regard to the degrading effect that the discharges would have on the surrounding or recipient environment. The monitoring of well tests was also inadequate because it was done without regard to the harm caused by those tests. Plaintiffs asserted that specific groundwater discharges degraded high-quality waters, as shown by the government's own adopted water quality standards. The Court concluded that:

... the right to a clean and healthful environment is a fundamental right because it is guaranteed by the Declaration of Rights found at Article II, Section 3 of Montana's Constitution, and that any statute or rule which implicates that right must be strictly scrutinized and can only survive scrutiny if the State establishes a compelling state interest and that its action is closely tailored to effectuate that interest and is the least onerous path that can be taken to achieve the State's objective.

In coming to its conclusion, the Court considered the meaning and scope of the environmental quality guaranteed by the Constitution. It examined the drafting history of the constitutional amendment, noting that the original proposal had no adjectives preceding the word environment. ${ }^{71}$ It quoted one delegate involved in the drafting as explaining that descriptive adjectives such as healthful or unsoiled were not included because:

The majority felt that the use of the word 'healthful' would permit those who would pollute our environment to parade in some doctors who could say that if a person can walk around

67. For example, Hawaii's Constitution, Art XI, s 9, is clear on the right and its justiciability: 'Each person has the right to a clean and healthful environment, as defined by law relating to environmental quality, including control of pollution and resources. Any person may enforce this right against any party, public or private, through appropriate legal proceedings'. See Life of the Land $v$ Land Use Comm'n of the State of Hawai'i, 623 P.2d 431 (Haw. 1981) (granting standing to an environmental organization which sought to challenge a reclassification of certain lands which were not owned by any of the organization's members. The Supreme Court held that the plaintiffs' 'aesthetic and environmental interests', were 'personal' rights guaranteed by Art 11, s 9 of the Constitution). See also, Richard v Metcalf, 921 P.2d 122 (Haw. 1997); Kahuna Sunset Owners Ass'n v Mahui County Council, 948 P.2d 122 (Haw. 1997).

68. Massachusetts guarantees the right to clean air and water, freedom from excessive and unnecessary noise and the natural scenic, historic and aesthetic qualities of their environment: Mass Const Art XLIX.

69. Montana's amendment provides 'The people shall have the right to clean air and water, freedom from excessive and unnecessary noise, and the natural, scenic, historic, and esthetic qualities of their environment; and the protection of the people in their right to the conservation development and utilization of the agricultural, mineral, forest, water, air and other natural resources is hereby declared to be a public purpose': Mont Const XLIX.

70. 296 Mont 207, 988 P.2d 1236 (1999).

71. See Montana Constitutional Convention, Vol IV at 1200, 1 March 1972; Mont Const Art IX, $\S 1(1)$. 
with four pounds of arsenic in his lungs or $\mathrm{SO} 2$ gas in his lungs and wasn't dead, that that would be a healthful environment. ${ }^{72}$

Other delegates countered that without descriptive adjectives, such as 'clean and healthful' prior to the term 'environment', the proposal lacked the force intended by its proponents. However the drafting committee expressed its concern that including the adjectives would actually permit degradation of Montana's environment, ${ }^{73}$ with one of its members suggesting that:

This country is going to have to address itself to the question of a healthful environment. What I'm concerned about is an environment that is better than healthful. If all we have is a survivable environment, then we've lost the battle. We have nothing left of importance. The federal government will see to it one way or another, if it's in its power, that we have an environment in which we can manage to crawl around or to survive or to in some way stay 'alive'. But the environment that I'm concerned about is that stage of quality of the environment which is above healthful; and if we put in the Constitution that the only line of defense is a healthful environment and that I have to show, in fact, that my health is being damaged in order to find some relief, then we've lost the battle; so I oppose this amendment. $^{74}$

In the end, it was agreed by both sides of the debate that the conventions intended to adopt whatever the delegates could agree was the stronger language; the adjectives were added. ${ }^{75}$ Based on this history, the Court concluded that the delegates intended to provide language and protections which were both anticipatory and preventive.

The delegates did not intend to merely prohibit that degree of environmental degradation which can be conclusively linked to ill health or physical endangerment. Our constitution does not require that dead fish float on the surface of our state's rivers and streams before its farsighted environmental protections can be invoked....

We conclude that the constitutional right to a clean and healthy environment and to be free from unreasonable degradation of that environment is implicated based on the Plaintiffs' demonstration that the pumping tests proposed by SPJV would have added a known carcinogen such as arsenic to the environment in concentrations greater than the concentrations present in the receiving water and that the DEQ or its predecessor after studying the issue and conducting hearings has concluded that discharges containing carcinogenic parameters greater than the concentrations of those parameters in the receiving water has a significant impact which requires review pursuant to Montana's policy of nondegradation.... ${ }^{76}$

72. Montana Constitutional Convention, Vol IV at 1201, 1 March 1972.

73. 'We did not want the Supreme Court of this state or the Legislature to be able to say that the environment in Montana, as we know right now, can be degraded to a healthful environment. So our purpose in leaving that word out was to strengthen it...': Montana Constitutional Convention, Vol V at 1243, 1 March 1972.

74. Montana Constitutional Convention, Vol V at 1243-44, 1 March 1972.

75. See Delegate McNeil cmts (Montana Constitutional Convention, Vol IV at 1209, 1 March 1972).

76. The Montana Supreme Court further applied its constitutional provision in the case CapeFrance Enterprises $v$ The Estate of Peed, 305 Mont 513, 29 P.3d 1011 (2001), in which it held that 'the protections and mandates of this provision apply to private action - and thus to private parties - as well' as to state action. Thus, 'it would be unlawful for Cape-France, a private business entity, to drill a well on its property in the face of substantial evidence that doing so may cause significant degradation of uncontaminated aquifers and pose serious public health risks'. 
Other national courts have similarly given broad reading to constitutional guarantees, and have done so through reference to national and international environmental standards. Article 24 of the South African Constitution provides that:

Everyone has a right to (a) to an environment that is not harmful to their health or well being; and (b) to have the environment protected, for the benefit of present and future generations, through reasonable legislative and other measures that (i) prevent pollution and ecological degradation; (ii) promote conservation; and (iii) secure ecologically sustainable development and use of natural resources while promoting justifiable economic and social development. ${ }^{77}$

The South African Constitutional Court explicitly relied on international environmental principles in giving substantive content to this Constitutional guarantee. Fuel Retailers Association of Southern Africa v Director-General Environmental Management, Department of Agriculture, Conservation and Environment, Mpumalanga Province and Others ${ }^{78}$ addressed the nature and scope of the obligations of environmental authorities when they make decisions that may have a substantial detrimental impact on the environment. The Court characterized the case as one that required the integration of the need to protect the environment with the need for social and economic development. In the Court's view, the international principle of sustainable development provided the applicable framework for reconciling these two needs. ${ }^{79}$

Sustainable development 'recognises that socio-economic development invariably brings risk of environmental damage as it puts pressure on environmental resources', but it envisages that decision-makers 'will ensure that socio-economic developments remain firmly attached to their ecological roots and that these roots are protected and nurtured so that they may support future socio-economic developments' ${ }^{80}$ In the Court's view, the National Environmental Management Act, which was enacted to give effect to section 24 of the Constitution, embraces the concept of sustainable development, defined to mean 'the integration of social, economic and environmental factors into planning, implementation and decision-making for the benefit of present and future generations'. In turn, this broad definition of sustainable development integrates environmental protection and socioeconomic development and incorporates the internationally recognized principle of intergenerational and intragenerational equity. ${ }^{81}$

The Court held that it would be a violation of the state's obligation under the constitution for it to grant specific performance of a contract for the sale of the land in question. See C Naber, 'Murky Waters: Private Action and the Right to a Clean and Healthful Environment - An Examination of Cape-France Enterprises v Estate of Peed' (2003) 64 Mont L Rev 357; B Thompson, 'Constitutionalizing the Environment: The History and Future of Montana's Environmental Provisions' (2003) 64 Mont L Rev 157.

77. S Afr Constt Ch IV, §24.

78. Case no CCT 67/06; ILDC 783 (ZA 2007). The case arose out of a decision by a provincial Department of Agriculture, Conservation and Environment to grant private parties permission to construct a filling station.

79. Ibid paras $56-57$.

80. Ibid para 58 .

81. Ibid para 59. In addition, NEMA sets out some of the factors that are relevant to decisions on sustainable development. These factors largely reflect international experience. But as NEMA makes it clear, these factors are not exhaustive. The Court quoted the factors set forth in the domestic National Environmental Management Act, Section 2(4)(a):

Sustainable development requires the consideration of all relevant factors including the following: 
The Court saw a second objective inherent in the Constitutional and legislative guarantees: to identify and predict the actual or potential impact of development and to consider ways of minimising negative impact while maximising benefit. Thirdly, and finally, the Court pointed out that NEMA requires application of the precautionary approach, 'a risk averse and cautious approach', that takes into account the limitation on present knowledge about the consequences of an environmental decision. This precautionary approach was seen to be especially important because NEMA requires that the cumulative impact of a development on the environmental and socioeconomic conditions be investigated and addressed. ${ }^{82}$ The precautionary principle required the authorities to insist on adequate precautionary measures to safeguard against the contamination of underground water. 'This principle is applicable where, due to unavailable scientific knowledge, there is uncertainty as to the future impact of the proposed development. Water is a precious commodity; it is a natural resource that must be protected for the benefit of present and future generations'. ${ }^{83}$

The Court thus set aside the decision of the environmental authorities and required reconsideration consistent with the judgment. As to the role of the courts in giving effect to environmental rights, the Court was clear:

The role of the courts is especially important in the context of the protection of the environment and giving effect to the principle of sustainable development. The importance of the protection of the environment cannot be gainsaid. Its protection is vital to the enjoyment of the other rights contained in the Bill of Rights; indeed, it is vital to life itself. It must therefore be protected for the benefit of the present and future generations. The present generation holds the earth in trust for the next generation. This trusteeship position carries with it the responsibility to look after the environment. It is the duty of the court to ensure that this responsibility is carried out. ${ }^{84}$

(i) That the disturbance of ecosystems and loss of biological diversity are avoided, or, where they cannot be altogether avoided, are minimised and remedied;

(ii) that pollution and degradation of the environment are avoided, or, where they cannot be altogether avoided, are minimised and remedied;

(iii) that the disturbance of landscapes and sites that constitute the nation's cultural heritage is avoided, or where it cannot be altogether avoided, is minimised and remedied;

(iv) that waste is avoided, or where it cannot be altogether avoided, minimised and reused or recycled where possible and otherwise disposed of in a responsible manner;

(v) that the use and exploitation of non-renewable natural resources is responsible and equitable, and takes into account the consequences of the depletion of the resource;

(vi) that the development, use and exploitation of renewable resources and the ecosystems of which they are part do not exceed the level beyond which their integrity is jeopardised;

(vii) that a risk-averse and cautious approach is applied, which takes into account the limits of current knowledge about the consequences of decisions and actions; and

(viii) that negative impacts on the environment and on people's environmental rights be anticipated and prevented, and where they cannot be altogether prevented, are minimised and remedied.

82. Section 24(7)(b) of NEMA provides 'Procedures for the investigation, assessment and communication of the potential impact of activities must, as a minimum, ensure ... investigation of the potential impact, including cumulative effects, of the activity and its alternatives on the environment, socio-economic conditions and cultural heritage, and assessment of the significance of that potential impact'.

83. Ibid para 98 .

84. Ibid para 102. 
Where no specific quality of environment is constitutionally guaranteed, national courts may still have jurisdiction to judge governmental action or inaction with reference to environmental laws and standards. Environmental protection laws in many, if not most, states, provide for citizen lawsuits as a means of enforcing legislative and regulatory standards. Such suits have played a significant role in enforcing clean air and water acts, ${ }^{85}$ as well as endangered species laws. As with human rights litigation, citizens sue the government to secure its performance of mandatory duties under the law; ${ }^{86}$ in addition, however, suits may be brought against regulated industries and other polluters in order to halt environmental harm. Courts have upheld citizen suit provisions and enforced substantive limits on permissible activities. In general, government officials are held to a due diligence standard. ${ }^{87}$ The criteria used to assess whether or not due diligence has been exercised could be useful in human rights cases to decide whether or not a government has taken the requisite measures to respect and ensure environmental rights. In general, due diligence is tested by whether or not the government sought compliance through an enforcement action against the actor causing harm; whether or not the government monitored the actor's activities after conclusion of the enforcement action and whether or not the penalties assessed provided adequate deterrence against repetition of the violation. ${ }^{88}$

At the international level, in the western hemisphere, the Inter-American Commission and Court have articulated the right to an environment at a quality that permits the enjoyment of all guaranteed human rights, despite a lack of reference to the environment in nearly all inter-American normative instruments. In the cases presented to these institutions, applicants have asserted violations of the rights to life, health, property, culture and access to justice, but some of them have also cited to guarantees of freedom of religion and respect for culture. The Commission's general approach to environmental protection has been to recognize that a basic level of environmental health is not linked to a single human right but is required by the very nature and purpose of human rights law:

The American Convention on Human Rights is premised on the principle that rights inhere in the individual simply by virtue of being human. Respect for the inherent dignity of the person is the principle which underlies the fundamental protections of the right to life

85. The US Clean Air Act of 1970, 42 USC $\$ 7604$, was the first of some 20 environmental statutes in the United States to provide for citizen enforcement by allowing suit to be brought for injunctive relief to force compliance and to require the Environmental Protection Agency (EPA) to perform mandatory duties imposed on it by the statute. See MD Axline, Environmental Citizen Suits (Butterworth Legal Publishers, Salem NH1995); JR May, 'Now More than Ever: Recent Trends in Environmental Citizen Suits' (2004) 10 Widener Law Review 8. The 1972 Clean Water Act, 33 USC $\$ 1365$, is similar, but also authorized citizens to sue polluters for civil penalties. Similar provisions exist in nearly all statutes under the authority of the EPA. 86. See, eg, Friends of the Earth $v$ United States EPA, 2006 US App LEXIS 10264 (DC Cir 2006)(successfully challenging the EPA determination that pollution caps under the Clean Water Act could be done on a seasonal or annual basis and not as daily loads).

87. Where the agency is engaged in appropriate enforcement of the law through judicial action, citizen suits are inadmissible. See Baughman v Bradford Coal Co, 592 F.2d 215, 219 (3rd Cir 1979), cert denied 441 US 961 (1979); PIRG of N.J. v Fritzsche, Dodge \& Olicott, Inc, 759 F.2d 1131 (3rd Cir 1985).

88. In Citzens for a Better Environment v Laidlaw Environmental Services (TOC), Inc., 890 F. Supp. 470 (DSC 1995), rev'd on other grounds, 149 F.3d 303 (4th Cir 1998); rev'd on other grounds, 528 US 167 (2000), a civil penalty of $\$ 100,000$ was considered inadequate and a citizen suit for additional penalties was allowed to proceed. 
and to preservation of physical well-being. Conditions of severe environmental pollution, which may cause serious physical illness, impairment and suffering on the part of the local populace, are inconsistent with the right to be respected as a human being. ${ }^{89}$

Similarly, using environmental standards, the European Court of Human Rights has given some indications of the quality of environment required to comply with the Convention's substantive guarantees. In its first major decision ${ }^{90}$ involving environmental harm as a breach of the right to private life and the home, guaranteed by Article 8 of the European Convention, the European Court held that severe environmental pollution may affect individuals' 'well-being' to the extent that it constitutes a violation of Article 8. The pollution need not reach the point of affecting health, if the enjoyment of home, private and family life are reduced and there is no fair balance struck between the community's economic well-being and the individual's effective enjoyment of guaranteed rights. ${ }^{91}$

The Court further explained the Lopez Ostra standard in Fadayeva v Russia, ${ }^{92}$ noting that because "no right to nature preservation is as such included among the rights and freedoms guaranteed by the Convention', the adverse effects of environmental pollution must attain a certain minimum level if they are to fall within the scope of Article 8. The requisite effects or interference need not reach the level of proven injury to health; it is enough if there are serious risks posed. ${ }^{93}$ In Fadayeva, the applicant succeeded on her claim because she was made more vulnerable to various diseases, even though quantifiable harm to her health was deemed not proved; in addition, the Court found that her quality of life at her home was adversely affected.

When the applicant's claim of interference is inadequate or subsidiary to concerns that do not fall within the scope of Article 8, the claim will be rejected. In Kyrtatos $v$ Greece ${ }^{94}$ the applicants complained of the noise and lights resulting from tourist development projects near their home. These complaints were not considered sufficiently serious to bring the case within the scope of Article 8, because the applicants had not asserted any deleterious consequences or serious impacts from the alleged pollution. The Court also seemed convinced, probably correctly, that the applicant's main claim concerned 'interference with the conditions of animal life in the swamp'. In the Court's view, such interference could not constitute an attack on the private or family life of the applicants. The Court referred to the fact that the applicants did not own the protected area. Thus, even though they alleged that the area, which adjoined their property, had lost all its scenic beauty and had changed profoundly in character from a natural habitat for wildlife to a tourist development filled with noise and light, the Court denied the Article 8 claim, reasoning that

89. Inter-Am Comm HR, Report on the Situation of Human Rights in Ecuador, OAS Doc OEA/Ser.L/V/II.96, Doc 10 Rev 1, 24 April 1997, at 92 (Report on Ecuador).

90. Lopez Ostra v Spain, (1994) Eur Ct Hum Rts Series A no 303C.

91. In Powell \& Raynor v United Kingdom (1990) Eur Ct Hum Rts Series A no 172, the European Court found that aircraft noise from Heathrow Airport constituted a violation of Article 8 but was justified as 'necessary in a democratic society' for the economic well-being of the country and was acceptable under the principle of proportionality because it did not 'create an unreasonable burden for the person concerned'. The latter test could be met by the State if the individual had 'the possibility of moving elsewhere without substantial difficulties and losses'. 92. Fadayeva v Russia, no 55723/00 (judgment of 9 June 2005) 2005/IV Eur Ct H R 255 (2005).

93. The evidentiary issues in this case are discussed at s $3 \mathrm{C}$.

94. Kyrtatos v Greece (App no 41666/98) Reports 2003-VI (22 May) (extracts). 
... even assuming that the environment has been severely damaged by the urban development of the area, the applicants have not brought forward any convincing arguments showing that the alleged damage to the birds and other protected species living in the swamp was of such a nature as to directly affect their own rights under Article 8 sec. 1 of the Convention. It might have been otherwise if, for instance, the environmental deterioration complained of had consisted in the destruction of a forest area in the vicinity of the applicants' house, a situation which could have affected more directly the applicants' own well-being. ${ }^{95}$

The Court has consistently held to the view that nature protection as such is not part of the Convention's guarantees. If such a guarantee exists under national law, however, there may be a separate claim for failure to enforce that law, as there was in this case. ${ }^{96}$

In deciding the merits of admissible cases, the Court has cited other instruments that refer to environmental quality. Taşkin and Others $v$ Turkey ${ }^{97}$ involved challenges to the development and operation of a gold mine, which the applicants alleged caused environmental damage to the detriment of people in the region. Appropriate procedures had been followed; the challenge was to the substance of the decision taken. Applicants had litigated the issue and won in domestic courts. The Turkish Supreme Administrative Court repeatedly concluded that the operating permit in issue did not serve the public interest and that the safety measures which the company had taken did not suffice to eliminate the risks involved in such an activity. Before the European Court, the applicants alleged a violation of Article 8.

In reviewing the applicable legal framework, the Court referred to Rio Principle 10 and the Aarhus Convention, as they set forth procedural rights. In addition, however, the Court quoted from a Parliamentary Assembly resolution on environment and human rights ${ }^{98}$ that was relevant to the substantive issues in the case. The Assembly resolution recommended that member states ensure appropriate protection of life, health, family and private life, physical integrity and private property, taking particular account of the need for environmental protection, and that member states recognize a human right to a healthy, viable and decent environment. The latter includes the objective obligation for states to protect the environment in national laws, preferably at the constitutional level. Given this recommendation and the domestic Constitutional guarantees, the Court found a violation despite the absence of any accidents or incidents at the mine. The mine was deemed to present an unacceptable risk.

The European Court's application of environmental standards reached a new level in a chamber judgment delivered 27 January 2009 in the case of Tatar $v$ Romania. The case arose in the aftermath of an ecological disaster at a gold mine in Romania, which resulted in high levels of sodium cyanide and heavy metals being released into local freshwaters. The contaminated water passed into the Tisza River in Hungary and eventually into the Danube River, causing pollution as far as the Black Sea. After two Romanians, father and son, were unable to achieve any accountability or redress through Romanian administrative and penal procedures, they brought an action in the European

95. Ibid para 53. On this point, the dissenting judge disagreed, unable to see a major difference between the destruction of a forest and the destruction of the extraordinary swampy environment, the applicants had been able to enjoy near their house before the development projects. 96. See (n 124) et seq.

97. Tasskin and Others v Turkey (App no 46117/99) (2004) Eur Ct H R 621 (10 November). 98. Parliamentary Assembly Recommendation 1614 (2003) of 27 June 2003. See also Okyay and Others $v$ Turkey (n 16). 
Court, alleging violations of Convention Articles 2 and 8. The Court decided to proceed with the case solely under Article 8 . As in other cases, the Court made note of the right to a healthy and balanced environment under the Romanian Constitution and of the domestic law implementing this right. It focused in large part on the procedural rights to information, public participation and redress, but it also considered the substantive obligations of the government under international environmental standards. The Court relied on UNEP findings about the causes and consequences of the accident, as well as WHO determinations about the health consequences of exposure to sodium cyanide, placing heavy reliance on them in the absence of adequate domestic fact-finding. The Court referred to international standards on best practices for the mining industry and, significantly, quoted extensively from the Stockholm Declaration on the Human Environment, the Rio Declaration on Environment and Development and the Aarhus Convention. It also included an extract from the ICJ's Gabcikovo Nagymaros judgment about environmental protection, resolutions of the Parliamentary Assembly, and legal texts of the European Union. Two of its conclusions were particularly important. First, the European Court declared in this case that the precautionary principle has moved, on the European level, from being a philosophical concept to being a juridical norm with content to be applied. This means the government must take action to adopt reasonable and adequate measures capable of respecting the rights of individuals against serious risks to their health and well-being, even where scientific certainty is lacking. Secondly, the Court recalls to Romania the obligation under Stockholm Principle 21 and Rio Principle 14 to prevent significant transboundary harm, in noting that both Hungary and Serbia were affected by the mining accident. These international norms, the Court finds, should have been applied by the Romanian government. It is the first time the Court has made reference to this obligation. Sadly, having unanimously found a violation of Article 8, the Court by a vote of five to two, rejected any compensatory damages for the applicants and awarded them only their costs of litigation.

Noise pollution cases often turn on compliance with local environmental laws. Where the state conducts inspections and finds that the activities do not exceed permissible noise levels established for the area, at least in the absence of evidence of serious and long-term health problems, the Court is unlikely to find that the State failed to take reasonable measures to ensure the enjoyment of Article 8 rights. ${ }^{99}$ In other words, where no specific environmental quality is guaranteed by the constitution or applicable human rights instrument, the courts accord considerable deference to the level of protection enacted by state or local authorities. ${ }^{100}$

\subsection{The scope of state obligations}

Enforcement of environmental rights involves courts in not only determining the mandated environmental quality, but also in assessing whether or not the government has taken the requisite actions to achieve that quality. This is not a strict liability standard, but the courts have not been entirely clear about what exactly is the standard of care

99. See, eg, Leon and Agnieszka Kania v Poland (App no 12605/03) 21 July 2009, para 102; Borysewicz, $v$ Poland (App no 71146/01) 1 July 2008, para 55.

100. See, eg, Hatton and Others $v$ the United Kingdom (GC) (App no 36022/97) Reports 2003-VIII. 
for governmental acts and omissions. Human rights tribunals have made clear that the state may be responsible whether pollution or other environmental harm is directly caused by the State or whether the State's responsibility arises from its failure to regulate properly private-sector activities. ${ }^{101}$ Human rights instruments require States not only to respect the observance of rights and freedoms but also to guarantee their existence and the free exercise of all of them against private as well as State actors. Thus any act or omission by a public authority which impairs guaranteed rights may violate a state's obligations. ${ }^{102}$ This is particularly important in respect to the environment, where most activities causing harm are undertaken by the private sector.

In the Inter-American system, positive obligations for the state to act derive not only from the generic obligations of Convention Article $1,{ }^{103}$ but also from specific rights, including Declaration Article I and Convention Article 4, which guarantee an individual's right to life. ${ }^{104}$ In the case of Yanomami v Brazil, ${ }^{105}$ the Inter-American Commission found that the government had violated the Yanomami rights to life, liberty and personal security guaranteed by Article I of the Declaration, as well as the right of residence and movement (Article 8) and the right to the preservation of health and wellbeing (Article 11), ${ }^{106}$ because the government failed to implement measures of 'prior and adequate protection for the safety and health of the Yanomami Indians'. ${ }^{107}$

The Yanomami case did not go into detail about the conduct required of a government or the standard of care the Commission would expect. Other cases and country studies have helped to clarify some issues in this respect, specifying that governments must enact appropriate laws and regulations, and then fully enforce them. In a country report on Ecuador, the Commission referred generally to the obligation of the state to respect and ensure the rights of those within its territory and the responsibility of the government to implement the measures necessary to remedy existing pollution and to prevent future contamination which would threaten the lives and health of its people, including through addressing risks associated with hazardous development activities, such as mining. ${ }^{108}$ Governments must regulate industrial and other activities that potentially could result in environmental conditions so detrimental that they create risks to health or life. ${ }^{109}$ Furthermore, the government must enforce the laws that it

101. See Mareno Gomez v Spain (App no 4143/02) 16 November 2004, para 55; Giacomelli v Italy, paras 78-79; Surugiu v Romania (App no 48995/99) 20 April 2004.

102. Velasquez Rodriguez Case, Inter-American Court of Human Rights Series C No 4 at 155 (Judgment of 29 July 1988) (concerning disappearance of civilians perpetrated by the Honduran army); Godinez Cruz Case, Inter-American Court of Human Rights Series C No 5 at 152-53 (Judgment of 20 January 1989).

103. Art 1 provides 'The States Parties to this Convention undertake to respect the rights and freedoms recognized herein and to ensure to all persons subject to their jurisdiction the free and full exercise of those rights and freedoms ...'. American Convention (n 15) Art 1.

104. Art 4(1) reads 'Every person has the right to have his life respected. This right shall be protected by law .... No one shall be arbitrarily deprived of his life'.

105. Yanomami Case, Res No 12/85, Case 7615 (Brazil), in Annual Report of the IACHR 1984-1985, OEA/Ser.L/V/II.66, Doc 10, Rev 1 (1985) 24.

106. Ibid 33.

107. Ibid 32.

108. Report on Ecuador (n 89) 94.

109. Ibid $\mathrm{p} v$. 
enacts as well as any constitutional guarantee of a particular quality of environment. ${ }^{110}$ The Commission was clear: 'Where the right to life, to health and to live in a healthy environment is already protected by law, the Convention requires that the law be effectively applied and enforced'. ${ }^{111}$

The State must also comply with and enforce the international agreements to which it is a signatory, whether these are human rights instruments or ones related to environmental protection. In the Ecuador report, the Commission noted that the state is party to or has supported a number of instruments 'which recognize the critical connection between the sustenance of human life and the environment', including the Additional Protocol to the American Convention in the Area of Economic, Social and Cultural Rights, ${ }^{12}$ the ICCPR and the ICESCR, the Stockholm Declaration, the Treaty for Amazonian Cooperation, ${ }^{113}$ the Amazon Declaration, ${ }^{114}$ the World Charter for Nature, ${ }^{115}$ the Convention on Nature Protection and Wildlife Preservation in the Western Hemisphere, ${ }^{116}$ the Rio Declaration on Environment and Development ${ }^{117}$ and the Convention on Biological Diversity. ${ }^{118}$ Through the standard-setting and enforcement process, the State must 'take the measures necessary to ensure that the acts of its agents ... conform to its domestic and inter-American legal obligations'. ${ }^{119}$

States thus are not exempt from human rights and environmental obligations in their development projects: 'the absence of regulation, inappropriate regulation, or a lack of supervision in the application of extant norms may create serious problems with respect to the environment which translate into violations of human rights protected by the American Convention' ${ }^{120}$ In the case of the Saramaka People v Suriname, ${ }^{121}$ the Inter-American Court set forth three safeguards it deemed essential to ensuring that development is consistent with human rights and environmental

110. In the Ecuador report, the Commission heard allegations that the Government had failed to ensure that oil exploitation activities were conducted in compliance with existing legal and policy requirements. The Commission's on site delegation also heard that the Government of Ecuador had failed to enforce the inhabitants' constitutionally protected rights to life and to live in an environment free from contamination. The domestic law of Ecuador recognizes the relationship between the rights to life, physical security and integrity and the physical environment in which the individual lives. The first protection accorded under Art 19 of the Constitution of Ecuador, the section which establishes the rights of persons, is of the right to life and personal integrity. The second protection establishes 'the right to live in an environment free from contamination'. Accordingly, the Constitution invests the State with responsibility for ensuring the enjoyment of this right and for establishing by law such restrictions on other rights and freedoms as are necessary to protect the environment. Thus the Constitution establishes a hierarchy according to which protections which safeguard the right to a safe environment may have priority over other entitlements: Ibid 78-86.

111. Ibid.

112. Protocol of San Salvador, 16 November 1999, OAS T.S. No. 69.

113. Treaty for Amazonian Cooperation (1978) 17 ILM 1045.

114. Amazon Declaration (1989) 28 ILM 1303.

115. World Charter for Nature GA Res $37 / 7$ (1982) UN Doc A/37/51.

116. Convention on Nature Protection and Wildlife Preservation in the Western Hemisphere (1940) 161 UNTS 229.

117. Rio Declaration on Environment and Development, supra n. 16.

118. Convention on Biological Diversity (1992) 31 ILM 818.

119. Report on Ecuador (n 89) 92.

120. Ibid 89.

121. Case of the Saramaka People v Suriname, Inter-American Court Human Rights Series C No 172 (28 November 2007). 
protection: (1) the state must ensure the effective participation of the members of the Saramaka people, in conformity with their customs and traditions, regarding any development, investment, exploration or extraction plan within Saramaka territory; (2) the state must guarantee that the Saramakas will receive a reasonable benefit from any such plan within their territory and (3) the state must ensure that no concession will be issued within Saramaka territory unless and until independent and technically capable entities, with the state's supervision, perform a prior environmental and social impact assessment. ${ }^{122}$ It is notable that these requirements parallel the Bonn Guidelines on Access and Equitable Benefit-Sharing, ${ }^{123}$ adopted pursuant to the Convention on Biological Diversity, although the Court does not cite them, referring instead to views of the UN Human Rights Committee, ${ }^{124}$ ILO Convention No 169, World Bank policies ${ }^{125}$ and the 2007 UN Declaration on the Rights of Indigenous Peoples. ${ }^{126}$ The Court viewed benefit-sharing as inherent to the right of compensation recognized under Article 21(2) of the Inter-American Convention. ${ }^{127}$

The European Court's jurisprudence is similar. The Court requires at a minimum that the State should have complied with its domestic environmental standards. ${ }^{128}$ The issue of compliance with domestic law is particularly important when there is a domestic constitutional right to environmental protection. The European Court will review governmental actions in the light of the domestic law. Okyay and Others $v$ Turkey ${ }^{129}$ concerned the failure of Turkish authorities to enforce constitutional rights and statutory environmental laws. The applicants had successfully challenged in domestic courts the operations of thermal power plants in Southwest Turkey, which they claimed would damage the environment and pose risks for the life and health of the Aegean region's population. They explicitly argued that Article 56 of the Turkish Constitution guaranteed them the right to live in a healthy and balanced environment. They did not argue that they had suffered any economic or other loss. The European Court agreed that they had a right under Turkish law to protection against damage to the environment and that their rights under Article 6(1) had been violated due to the failure of Turkish authorities to comply in practice and within a reasonable time with the domestic court's judgments.

Domestic constitutional laws and provisions are also important in cases where the applicants have no independent claim under the European Convention for severe pollution but instead are seeking nature protection or protection of the environment more

122. Ibid para 129. The holding may be limited to indigenous and tribal peoples.

123. Bonn Guidelines on Access to Genetic Resources and Fair and Equitable Sharing of the Benefits Arising out of their Utilization, Decision VI/24, COP VI, Convention on Biological Diversity, available at http://www.cbd.int/decision/cop/?id=7198, last accessed 13 November 2009.

124. See ICCPR 'General Comment no 23' in 'The Rights of Minorities (Art 27)' (4 August 1994) UN Doc CCPR/C/21 Rev 1/Add.5 and Apirana Mahuika et al v New Zealand, (15 November 2000) UN Doc CCPR/C/70/D/47/1993.

125. See World Bank, Revised Operational Policy and Bank Procedure on Indigenous Peoples, OP/BP 4.10.

126. UN Declaration on the Rights of Indigenous Peoples, approved by the General Assembly 14 September 2007.

127. Art 21(2) provides that [n]o one shall be deprived of his property except upon payment of just compensation, for reasons of public utility or social interest, and in the cases and according to the forms established by law.

128. See, eg, Ashworth and Others v United Kingdom, (App no 39561/98) 20 January 2004; Moreno Gomes v Spain (2005) Eur Ct HR 2004-X 327.

129. Okyay and Others v Turkey (n 16) 57. 
generally. In Kyrtatos $v$ Greece,$^{130}$ as in the Okyay case, the applicants' claim involved a constitutional provision protecting the environment. In the domestic courts, the applicants and the Greek Society for the Protection of the Environment and Cultural Heritage asserted that the local prefect's decisions to allow development projects, and consequently building permits, were illegal because the area concerned was a swamp safeguarded by Article 24 of the Greek Constitution, which protects the environment. The domestic court held that the prefect had violated Article 24 of the Constitution, because the decision put in jeopardy an important natural habitat for various protected species, including birds, fishes and sea turtles. It followed that the building permits were also unlawful and had to be quashed. The decision was not enforced by the local authorities, who instead issued further building permits. Given the constitutional provision, the European Court found a violation of Article $6(1)$, because the domestic law gave environmental rights to the applicants and the government had failed to enforce them.

The African Commission also has identified governmental obligations in this field by reference to environmental norms. In SERAC v Nigeria, the African Commission held that Article 24 'imposes clear obligations upon a government to take reasonable and other measures to prevent pollution and ecological degradation, to promote conservation, and to secure an ecologically sustainable development and use of natural resources'. ${ }^{131}$ Compliance with these obligations includes ordering or permitting independent scientific monitoring of threatened environments, requiring environmental and social impact studies, monitoring hazardous materials and activities, as well as providing information and an opportunity for the public to participate in decisionmaking. ${ }^{132}$ While the Commission did not cite to specific environmental agreements, the obligations it mentions are part of international environmental law.

Beyond ensuring that any domestic environmental rights are enforced, the European Court scrutinizes the adequacy of the domestic law to see if the State has ensured a fair balance between the interests of the community and the rights of those affected. The Court accords each state a wide margin of appreciation in this respect, because national authorities 'are in principle better placed than an international court to assess the requirements' in a particular local context and to determine the most appropriate environmental policies and individual measures while taking into account the needs of the local community, ${ }^{133}$ especially in a technical sphere like environmental protection. ${ }^{134}$ The wide margin of appreciation afforded governments means that the Court will only find a violation if there is a "manifest error of appreciation' by the national authorities in striking a fair balance between the competing interests of the different private actors. ${ }^{135}$ The final evaluation as to whether the justification given by the State is relevant and sufficient remains subject to review by the Court, ${ }^{136}$ but 'only in exceptional circumstances' will the court look beyond the procedures followed to disallow the conclusions reached by domestic authorities on the environmental protection measures to be taken on the projects and activities

130. Kyrtatos v Greece (n 94).

131. Social and Economic Rights Action Center/Center for Economic and Social Rights $v$ Nigeria (27 May 2002) Comm 155/96, Case No ACHPR/COMM/A044/1.

132. Ibid para 53.

133. Giacomelli (n 101) para 80.

134. Fadayeva v Russia (n 92) para 104, citing Hatton para 122.

135. Ibid.

136. Ibid paras 102-103. 
allowed to proceed. ${ }^{137}$ Even if it finds that the State decided wrongly, the Court will not determine exactly what should have been done to reduce the pollution in a more efficient way. ${ }^{138}$

Another human rights supervisory body has also found violations of substantive guarantees due to the failure of the government to legislate to protect the environment. The first and, to date, only European Social Charter complaint to concern environmental conditions, lodged 4 April 2005, claimed violations of the Charter's right to health provisions ${ }^{139}$ because the State had not adequately prevented negative environmental impacts nor had it developed an appropriate strategy to prevent and respond to the health hazards stemming from lignite mining. The complaint also alleged that there was no legal framework guaranteeing security and safety of persons working in lignite mines. The European Committee of Social Rights concluded that the government had violated the Charter. ${ }^{140}$ On the issue of the right to health (Article 11), the Committee examined the Greek National Action Plan for greenhouse gas emissions and found it inadequate in the light of the State's obligations under the Kyoto Protocol and the principle requiring use of the 'best available techniques'. ${ }^{141}$ While the Committee found that Greek regulations on information and public participation were satisfactory, the evidence showed 'that in practice the Greek authorities do not apply the relevant legislation satisfactorily'. Very little had been done to organize systematic epidemiological monitoring of those concerned and no morbidity studies had been carried out.

The imposition of substantive environmental quality standards does not exclude but rather reinforces procedural rights. Indeed, human rights tribunals have read the procedural rights and corresponding State obligations into substantive human rights guarantees such as the right to life and to privacy and home life. This approach has been important in instances where the guarantees of procedural rights in human rights instruments are not strong, as is the case in the European Convention. In Guerra v Italy, ${ }^{142}$ the applicants alleged that the Italian authorities violated Convention Articles 2,8 and 10 by failing to mitigate the risk of a major accident at a nearby chemical factory and by withholding information from local residents about the risks and emergency procedures. The 'right to information' claim was dismissed, because the European Convention does not require the collection and dissemination of information about the environment, but the European Court effectively incorporated this requirement

137. Ibid para 105, citing Taskin (n 97).

138. In particular, the Court says it would be going too far to assert that the State or the polluting undertaking were under an obligation to provide the applicant with free housing: Para 133. It is enough to say that the situation called for a special treatment of those living near the plant. 139. Marangopoulos Foundation for Human Rights (MFHR) v Greece Complaint No 30/2005. 140. The Committee transmitted its decision on the merits to the Committee of Ministers and to the Parties on 6 December 2006. The Committee of Ministers adopted its resolution on the matter on 15 January 2008.

141. According to the Committee, ' $[\mathrm{t}] \mathrm{he}$ Greek National Action Plan for 2005-2007 (NAP1) provides for greenhouse gas emissions for the whole country and all sectors combined to rise by no more than $39.2 \%$ until 2010, whereas Greece was committed, in the framework of the Kyoto Protocol, to an increase in these gases of no more than $25 \%$ in 2010 . When air quality measurements reveal that emission limit values have been exceeded, the penalties imposed are limited and have little dissuasive effect. Moreover, the initiatives taken by DEH (the public power corporation operating the Greek lignite mines) to adapt plant and mining equipment to the "best available techniques" have been slow'.

142. Guerra v Italy (App no 14967/89) Reports 1998-I, no 64. 
into the applicant's Article 8 claim as the 'procedural dimension' of the obligation of states to secure effective respect for the applicants' right to family and home life.

In Oneryildiz v Turkey, ${ }^{143}$ the European Court of Human Rights made reference to several environmental texts, both binding and nonbinding in holding the Turkish government responsible for the loss of life and property resulting from a methane explosion at a waste site. The binding texts deemed relevant were the Lugano Convention on hazardous activities ${ }^{144}$ and the Strasbourg Convention on Protection of the Environment through Criminal Law. ${ }^{145}$ The European Court used the Lugano Convention to define 'dangerous activity' and 'damage' incurring the liability of public authorities. It noted the duty under the Strasbourg Convention for authorities to establish criminal offences for loss of life involving the disposal or treatment of hazardous wastes.

The Court also made reference in particular to nonbinding Council of Europe texts, including Parliamentary Assembly Resolution 587 (1975) on problems connected with the disposal of urban and industrial waste, Resolution 1087 (1996) on the consequences of the Chernobyl disaster and Recommendation 1225 (1993) on the management, treatment, recycling and marketing of waste. In addition to Parliamentary Assembly texts, the Court cited the Committee of Ministers Recommendation No. $\mathrm{R}(96) 12$ on the distribution of powers and responsibilities between central authorities and local and regional authorities with regard to the environment.

On the merits of this case, the Court explained that the right to life provision, Article 2 of the European Convention 'must be construed as applying in the context of any activity, whether public or not, in which the right to life may be at stake, and a fortiori in the case of industrial activities, which by their very nature are dangerous, such as the operation of waste-collection sites'. According to European standards, waste disposal is a hazardous activity, therefore Article 2 applies. The resulting duty of care depends on several factors: the harmfulness of the phenomena inherent in the activity, the contingency of the risk to the applicant, the status of those involved in creating the risk and whether or not the conduct was deliberate. The court merged procedural rights into the substantive evaluation, finding that 'particular emphasis' should be placed on the public's right to information concerning the risks to life and the duty to investigate when loss of life occurs. ${ }^{146}$ Assessing the evidence, the Court found that the authorities must have known of the risk and of the need to take preventive measures 'particularly as there were specific regulations on the matter'. ${ }^{147}$ As such they had an obligation as well under Convention Article 2 'to take such preventive measures as were necessary and sufficient to protect those individuals...'. ${ }^{148}$ The government failed in its duty.

Like Oneryildiz, the case of Budayeva and Others $v$ Russia ${ }^{149}$ concerned governmental knowledge of hazards and the failure to act upon that knowledge. The difference

143. Oneryildiz v Turkey (n 49).

144. Convention on Civil Liability for Damage resulting from Activities Dangerous to the Environment (Lugano 21 June 1993) ETS No 150.

145. Convention on Protection of the Environment through Criminal Law (Strasbourg 4 November 1998) ETS No 172. The Court noted that the Strasbourg Convention was not in force, but found it "very much in keeping with the current trend towards harsher penalties for damage to the environment'.

146. Ibid para 90 .

147. Ibid para 101.

148. Ibid.

149. Budayeva and Others $v$ Russia (App no 15339/02) \& Ors (20 March 2008). 
was that the latter case involved repeated natural disasters rather than hazards originating in human activities. The standard of care did not differ appreciably, however. Governmental authorities aware of mudslide hazards in a mining district failed to take reasonable precautions, with resulting deaths in a village and loss of property. The applicants pleaded violations of Article 2 (right to life) and Protocol 1, Article 1 (right to property). The Court held the government responsible for the loss of life but found that the causal link was not established in respect of the latter claims. The applicants could not demonstrate that 'but for' the official failures to act, their property would have been safe. The July 2000 mudslide was of unprecedented severity.

Looking at the substantive aspect of the Russian government's obligations respecting dangerous activities, the Court placed special emphasis on the adoption of regulations geared to the special features of the activity in question, particularly with regard to the level of the potential risk to human life. ${ }^{150}$ Such regulations must govern the licensing, setting up, operation, security and supervision of the activity and must make it compulsory for all those concerned to take practical measures to ensure the effective protection of citizens whose lives might be endangered by the inherent risks. ${ }^{151}$ Supervision and monitoring are also required. The choice of particular practical measures is in principle a matter within the State's margin of appreciation and the Court will seek to avoid placing an impossible or disproportionate burden on authorities. ${ }^{152}$

After the Court requested the government to provide information on its regulatory framework, land-planning policies and specific safety measures implemented at the relevant time to respond to natural hazards, the Court found that the measures were limited to a mud-retention dam and collector that were not adequately maintained. The Court held that there was no justification for the failure to act regarding foreseeable mortal risks to the residents of the town and there was a causal link between that failure and the death and injuries suffered in the mudslide. Accordingly there was a violation of Article 2.

The wide margin of appreciation afforded in environmental matters, due to their technical complexity and the variations in State priorities and resources, is given even greater weight in the sphere of emergency relief after the fact in responding to weather events. The Court held that the State's positive obligation is less in the context of natural disasters, 'which are as such beyond human control', than in the sphere of dangerous activities of a man-made nature. The right to peaceful enjoyment of possessions, which is not absolute, requires only that the state do what is reasonable in the circumstances. ${ }^{153}$ The standard of care is different and higher when the risk involves potential loss of life. The State in this situation has a positive obligation to do everything within the authorities' power in the sphere of disaster relief for the protection of the right to life. The origin of the threat and the extent to which one or another risk is susceptible to mitigation are factors to be evaluated in determining the scope of the state's positive obligations. ${ }^{154}$ The Court found that the authorities had

150. Ibid para 132.

151. Ibid.

152. Ibid para 135.

153. Ibid para 174. While the Court found that the measures taken by the state were negligent, it found the causal link was not well-established. The mudslide of 2000 being exceptionally strong, the Court said it was unclear whether a functioning warning system or proper maintenance of the defence infrastruction would have mitigated the damage.

154. Ibid para 137. 
been given warnings about the risks, including the state of disrepair of the dam, and had failed to provide resources for strengthening the defence infrastructure resources that became available immediately after the mudslide. The government provided no explanation and the Court concluded that the restoration of the defence infrastructure between 1999 and 2000 was 'not given proper consideration by the decision-making and budgetary bodies prior to the hazardous season of 2000' ${ }^{155}$ Nor were any alternative land-planning policies being implemented or monitoring stations set up. The Court noted that the public's procedural right of information can only be implemented if the government obtains the relevant information, which in this case was indispensable for ensuring the residents' safety. The authorities' failure to ensure the functioning of an early warning system was, thus, also unjustified.

\subsection{Causality, evidence and precaution}

Assessing risk is an important issue in litigating substantive environmental rights. Some human rights procedures limit standing to 'victims' of violations, and there must be a sufficient threat for the applicants or petitioners to qualify as a victim. ${ }^{156}$ The precautionary principle has begun to play a role in bringing more risks within the ambit of human rights litigation.

The Taşkin case described above was one based on risk, stemming from the use of cyanide in gold extraction. The Court referred to the various evaluations that had been done on site, which highlighted the risks. Domestic judicial findings also demonstrated the threat to the environment and lives of the neighbouring population. The Court found Article 8 to be applicable 'where the dangerous effects of an activity to which the individuals are likely to be exposed have been determined as part of an environmental impact assessment procedure in such a way as to establish a sufficiently close link with private and family life for purposes of Article 8 of the Convention' ${ }^{157}$ (emphasis added). The Court held that this broad reading was necessary to ensure the effectiveness of Article 8.

The evidentiary basis of the Tasskin decision was the domestic court judgment. The Court also held that 'in view of' the conclusion of the domestic court on the absence of a public interest in allowing the gold mine, it did not need to examine the case from the perspective of the normal wide margin of appreciation afforded governments in environmental matters. Therefore, there was a violation of Article 8.

The problem of fact-finding and lack of expertise is frequently said to be a hurdle to giving substantive content to environmental rights. At the international level, this has not proved to be a high hurdle thus far, because in most of the cases domestic fact-finding had already revealed the risks entailed or the consequent harm. This was the case in Oneryildiz, Taşkin ${ }^{158}$ and Fadayeva. ${ }^{159}$ In the last-mentioned case,

155. Ibid para 149.

156. See Bordes and Temeharo v France (30 July 1996) Comm No 645/1995, CCPR/C/57/D/ $645 / 1995$. The risk of harm from nuclear radiation due to nuclear testing by France in the South Pacific was deemed too remote for the victims to qualify as victims.

157. Taşkin (n 54) para 113.

158. Ibid.

159. Fadayeva v Russia (n 92). See also Ledyayeva Dobrokhotova, Zolotareva and Romashina $v$ Russia, nos 53157/99, 53247/99, 53695/00 and 56850/00 (judgment of 26 October 2006) also involving the same steel plant built during the Soviet era. 
a government decree had recited statistics on the increases in respiratory and blood diseases linked to air pollution, as well as the increased number of deaths from cancer. ${ }^{160}$ The government had also determined by legislation the safe levels of various polluting substances, many of which were exceeded in the security zone where the applicant lived. The mayor of the city said the steel plant was responsible for more than $95 \%$ of industrial emissions into the town's air, ${ }^{161}$ while a State Report on the Environment indicated that the plant in question was the largest contributor to air pollution of all metallurgical plants in Russia. The two statements reduced questions about causality. ${ }^{162}$ In the end, both parties agreed that the applicant's place of residence was affected by industrial pollution caused by the steel plant, but they disagreed over the degree and effects of the pollution. The government claimed that the disturbance caused by the pollution was not so severe as to raise an issue under Article 8. The applicant and the European Court disagreed. The Court elaborated on its test for finding that environmental conditions are sufficiently severe to be encompassed within the guarantees of Article 8:

The assessment of that minimum is relative and depends on all the circumstances of the case, such as the intensity and duration of the nuisance, and its physical or mental effects. The general context of the environment should also be taken into account. There would be no arguable claim under Article 8 if the detriment complained of was negligible in comparison to the environmental hazards inherent to life in every modern city.

Causality was an issue on the applicant's health claims. Her medical records indicated problems but did not attribute them to any specific causes. The doctors stated, however, that her problems would be exacerbated by working in conditions of vibration, toxic pollution and an unfavourable climate. ${ }^{163}$ The applicant also submitted an expert report ${ }^{164}$ which linked the plant specifically to increased adverse health conditions of persons residing nearby. The Court found that the medical evidence did not establish a causal link between the pollution at her residence and her illnesses, but accepted that the evidence, include submissions by the government, was clear about the unsafe excessive pollution around her home. The Court also made reference to the expert report and the findings of the domestic courts. The Court noted that Russian legislation defined the maximum permissible concentrations as 'safe concentrations of toxic elements'. Therefore, exceeding these limits produced a presumption of unsafe conditions potentially harmful to health and well-being of those exposed to it. This presumption, together with the evidence submitted, led the court to conclude that the applicant's health deteriorated as a result of her prolonged exposure to the industrial emissions from the steel plant. Alternatively, even if that harm could not be

160. Russia's Constitution, Art 42 guarantees as follows: 'Everyone has the right to a favorable environment, to reliable information about its state, and to compensation for damage caused to his health or property by ecological disease'. The provision was not invoked in the case.

161. The Court noted that this made the case different from and more easily definable than other air pollution cases where multiple minor sources cumulate to produce the problem.

162. The Court noted that the parties produced official documents containing generalized information on industrial pollution, because basic data on air pollution are not publicly available. Para 30.

163. Fadayeva v Russia (n 92) para 45.

164. The Court made it a point to recite the qualifications of the expert when discussing the report. See ibid para 46 (n 1). 
quantified, the pollution 'inevitably made the applicant more vulnerable to various illnesses' and affected her quality of life at home. ${ }^{165}$ Therefore Article 8 applied.

The European Court's standard of proof is high, ${ }^{166}$ but flexible, and takes into account the fact that governments often are the sole repository of relevant evidence. In a subsequent case involving the same Russian steel mill as was the subject of the Fadayeva judgment, the Court explained:

There is no doubt that serious industrial pollution negatively affects public health in general. However, it is often impossible to quantify its effects in each individual case, and distinguish them from the influence of other relevant factors, such as age, profession, etc. The same concerns possible worsening of the quality of life caused by the industrial pollution. The "quality of life' is a very subjective characteristic which hardly lends itself to a precise definition. Therefore, taking into consideration the evidentiary difficulties involved, the Court has no other choice than to repose trust primarily, although not exclusively, in the findings of the domestic courts and other competent authorities in establishing factual circumstances of the case.... However, the Court cannot rely blindly on the decisions of the domestic authorities, especially when they are obviously inconsistent or contradict each other. In such situations it has to assess the evidence in its entirety. ${ }^{167}$

The European Court took into account that 'it was widely recognized' that the environmental situation was unfavourable for the residents of the town around the steel mill and adversely affected their health and well-being.

The analysis raises the question of what other evidence is sufficient to raise the presumption of harm that the Court creates in the Fadayeva case. It should not be limited to legislative findings, because, as Zander $v$ Sweden indicates, safe levels may be changed to accommodate economic interests without necessarily being based on sound science. The WHO and other scientific bodies have determined through epidemiological studies what constitutes safe levels of concentration of toxic, carcinogenic, mutagenic and other hazardous substances. ${ }^{168}$ Reliable evidence from such studies can and should be introduced to demonstrate presumed harm when such levels are exceeded, even if local legislation permits higher concentrations. A petition to the Inter-American Commission, recently declared admissible, relies on such WHO standards to assert that the average sulphur dioxide levels from a metallurgical complex are detrimental to the lives and health of the nearby community in Peru. ${ }^{169}$

In the case of Fägerskiöld v Sweden, ${ }^{170}$ the Court cited to WHO guidelines ${ }^{171}$ on noise pollution, in rejecting the admissibility of an application concerning wind turbines constructed and operating near the applicants' property. The Court noted that the guidelines are set at the level of the lowest adverse health effect associated

\section{Ibid para 88 .}

166. It has long demanded 'proof beyond reasonable doubt'. Fadayeva (n 92) para 79, which can follow from the coexistence of sufficiently strong, clear and concordant inferences or of similar unrebutted presumptions of fact.

167. Ledyayeva (n 157) para 90.

168. The WHO has developed guidelines for safe and acceptable water quality and quantity. World Health Organization, 'Guidelines for Drinking Water Quality' (3rd edn 2004). Independent surveillance of water quality, quantity, accessibility, affordability and long-term availability are part of the WHO framework.

169. Inter-American Commission on Human Rights, Report No 76/09, Case 12.718, Сотmunity of La Oroya, Peru, admissibility decision of 5 August 2009, OAS/Ser/L/V/II.135, Doc 23. 170. Fägerskiöld v Sweden (App no 37664/04) (admissibility) 26 February 2008.

171. World Health Organization, 'Guidelines for Community Noise' (Geneva 1999). 
with noise exposure. The Court also referred to even lower maximum levels adopted by most European countries. Applying these standards to the noise level tests submitted in the case, the Court found that the levels of noise did not exceed the WHO guidelines and were minimally above the recommended maximum level in Sweden. Therefore the environmental nuisance could not be found to reach the level of constituting severe environmental pollution. The Court also rejected the applicants' claims that their property rights were violated because the wind turbines decreased the value of their property. Assuming that there was an interference with property rights, the Court found that it was justified on several grounds, one of them being that the operation of the wind turbines was in the general interest as it is an environmentally friendly source of energy which contributes to the sustainable development of natural resources. The Court considered whether these beneficial environmental consequences were sufficient to outweigh the negative impact on the applicants. The Court reiterated its findings that the negative consequences were not severe, while the availability of renewable energy is beneficial for both the environment and society. Moreover the government had taken measures to mitigate the negative impacts on the applicants. In sum, the alleged interference was proportionate to the aims pursued and no violation of property rights occurred.

In the Greek case on lignite mining, ${ }^{172}$ the European Social Charter Committee relied on what it called 'ample and unambiguous scientific evidence' that lignitecaused air pollution has a harmful effect on human health and life, without specifying the health risks. Despite the beneficial impacts of lignite use in providing energy independence, access to electricity at a reasonable cost and economic growth, the Committee found that the government's actions violated the State's national and international obligations to combat pollution that caused health problems. It pointed to the right to environment in the Greek constitution, as well as national environmental protection legislation and regulations, noting that these were not applied and enforced in an effective manner. In sum, Greece had not struck a reasonable balance between the interests of persons living in the lignite mining areas and the general interest, and there was thus a violation of the right to protection of health under the Charter.

\section{CONCLUSIONS: ISSUES OF LAW OR POLICY?}

The difficulties facing courts presented claims based on substantive environmental rights are significant, at least when the government has made some effort to address environmental protection. The deferential standard of review adopted by the European Court is echoed in domestic courts which make efforts to determine when domestic laws and policies are so deficient that they run afoul of human rights guarantees. In Clean Air Foundation Limited \& Gordon David Oldham v The Government of the Hong Kong Special Administrative Region, ${ }^{173}$ the applicants sought judicial review of the authorities' alleged failure to take the necessary measures to combat air pollution. The applicants contended that Hong Kong's air is so polluted that it is poisoning the people who live there, shortening their lives in breach of the Bill

172. Marangopoulos Foundation for Human Rights v Greece (Complaint No 30/2005) European Committee on Social Rights (2006).

173. CAL 35/2007, Court of First Instance, Constitutional and Administrative Law List, No 35 of 2007 (Judgment of 26 July 2007). 
of Rights and various international covenants which have been extended to Hong Kong, in particular the right to health as set forth in Article 12 of the International Covenant on Economic, Social and Cultural Rights. ${ }^{174}$ The Court accepted that Article 12 imposes a duty on state authorities to combat air pollution, even if it cannot be an absolute duty to ensure with immediate effect the end of all pollution. Nonetheless the Court held that the issue was one of policy, not law. It stated: 'A policy may, of course, be unlawful. But because a policy is considered to be unwise, short-sighted or retrogressive does not make it unlawful. It has long been accepted that policy is a matter for policy-makers and that to interfere with the lawful discretion given to policymakers would amount to an abuse of the supervisory jurisdiction vested in the courts'. ${ }^{175}$ The applicants submitted that they did not seek merely to review the wisdom of government's policies in respect of air pollution, but rather to determine whether the Government had met its obligations in law. The Court was unable to agree, finding that the real issues in the case were not issues of legality and did not go to the Government acting outside of its powers. Instead, they went to the question of why the Government had not chosen to pursue certain policies.

Some commentators have questioned whether legally trained, nontechnical judges are the appropriate arbiters of a clean and healthy environment and whether the judicial branch of government is the appropriate venue for resolving these value-laden, science-based environmental decisions. ${ }^{176}$ As the Hong Kong case illustrates, a number of judges have expressed similar concerns about the institutional capacity and propriety of court involvement in environmental decision-making.

Adjudicating cases under broadly worded standards is not new for judges, however, nor is it uncommon for them to be faced with adjudicating highly technical matters. Courts must regularly, and on a case-by-case basis, define what constitutes 'reasonable', 'fair', or 'equitable' conduct. With the adoption of constitutional environmental rights provisions and increasing acceptance of the links between environmental degradation and the violation of other human rights, national and international tribunals struggle to give substance to environmental rights without overstepping the judicial function. In general, courts have taken the view that such enactments serve to place environmental protection in a position superior to ordinary legislation. Over time, courts tend to create a balancing test to avoid too readily undoing the deliberative decisions reached by the political branches of government.

Human rights law is not about stopping all human activities but about recognizing that they utilize scarce resources and produce emissions and waste that inevitably have individualized and cumulative environmental impacts. These impacts have to be considered, measured and monitored, with the result that some activities will be limited or prohibited. Environmental science helps determine the causal links

\section{Article 12 reads.}

1. The States Parties to the present Covenant recognize the right of everyone to the enjoyment of the highest attainable standard of physical and mental health.

2. The steps to be taken by the Stats Parties to the present Covenant to achieve the full realization of this right shall include those necessary for:

(a) ...

(b) The improvement of all aspects of environmental and industrial hygiene....

175. Ibid.

176. B Thompson, Jr., 'Constitutionalizing the Environment: The History and Future of Montana's Environmental Provisions' (2003) 64 Mont L Rev 157-58. 
120 Journal of Human Rights and the Environment, Vol. 1 No. 1

between the activities and the impacts, giving courts a set of data on which to base decisions about whether or not a proper balance of interests has been obtained, one which ensures an equitable outcome and minimizes the risk of harm to the environment and human rights. The substance of environmental rights involves evaluating ecological systems, determining the impacts that can be tolerated and what is needed to maintain and protect the natural base on which life depends. Environmental quality standards, precaution, and principles of sustainability can establish the limits of environmental decision-making and continue to give specific content to environmental rights in law. 